(2)

\title{
Identity and Dissent in James Joyce's A Portrait of the Artist as a Youngman and D. H. Lawrence's The Rainbow
}

\author{
Athanasius A. Ayuk.
}

Department of English, Higher Teacher Training College, University of Yaoundé 1, Cameroon

Received: 28 Oct 2020; Received in revised form: 06 Jan 2021; Accepted: 22 Jan 2021; Available online: 06 Feb 2021

(C2021 The Author(s). Published by Infogain Publication. This is an open access article under the CC BY license

(https://creativecommons.org/licenses/by/4.0/).

\begin{abstract}
The last decades of the nineteenth century were a culmination of years of social, political, and economic change in Europe and in the United Kingdom. These changes occasioned a cultural revolution that will see the rapid dissolution of the organic fabric of the British society and elicit questions about the very morality that was the foundation of English society. D. H. Lawrence and James Joyce chronicled these social and moral tensions in The Rainbow and A Portrait of the Artist as a Young Man. This paper interrogates the nexus between identity and dissent in the protagonists' attempts to navigate their moral world. It equally seeks to understand the moral compass of religion, country, and family in the assertion of individual identity and how these define the cultural collective consciousness of the era in which they were produced and the birth of alternative truths.
\end{abstract}

Keywords - Identity, dissent, morality, collective consciousness.

Identity and dissent are the hallmarks of Modern English Literature. They are not simply the results of major historical, scientific and philosophical developments of the period, but the result of a gradual process of change occasioned by the desire to create new existential paradigms ${ }^{1}$.The major conflicts of the twentieth century with their attendant consequences required new inquiry into human society and humankind's relationship to it. Amongst some of the consequences was the geographic reorganization of the world, which created a new sense of identity in some and bitterness in others. It sparked strong feelings of nationalism in erstwhile dominated peoples. ${ }^{2}$ It occasioned a

\footnotetext{
${ }^{1}$ Such changes as inventions of the airplane, the television, the radio, the computer, the automobile, antibiotics, the computer, and the internet were to improve on the quality of man's life but also create additional existential angst.

${ }^{2}$ For more informtaion on this see Hans Kohn's and Wallace Sokolsky's African Nationalism in the twentieth Century (Princeton,N.J.:Van Nostrand,1965) and Oliver Zimmer's
}

new psychological map of the world and created a social chasm, the direct result of the experience of war and the consequent inevitable changes.

The desire to break away from what was considered at the time as a moribund social set up was symptomatic of an age sick of itself. The young and adventurous thought of the necessity to overthrow a bedeviled traditional and regal European society, build on class and hegemony. Two writers, James Joyce and D. H. Lawrence, stand out in this miasma of doubt and anxiety, representing divergent and convergent views on identity and dissent in the modern English novel. Even though the relationship between Lawrence and Joyce was not very friendly from a personal and literary perspective as Earl Ingersoll argues, they are both modernists all attempting to fathom the nature of human beings and the human society. Ingersoll calls them an

Nationalism in Europe, 1890-1940 (Basingstoke: Palgrave Mcamillan,2003) 
"odd couple" (2) because even though modernist, they were different and treated each other's work with disdain. Despite this turmoil, one can read their shared concern with the individual character struggling to find purpose.

Joyce's A portrait of the Artist as a Youngman and Lawrence's The Rainbow reflect two currents of identity and dissent in English Literature. For Joyce, the fundamental concern is that of national identity weaved in the text through Stephen Dedalus' struggle to come to terms with both himself and his country. And for Ursula Brangwen ${ }^{3}$ it plays out in her struggle towards social recognition and the affirmation of her own personal views and values. These two writers, in spite the fact of their being antipodal to each other in many respects, simply forge newparadigm shifts which are both natural and inevitable.They represent the culminating point of years of dissent in painting, sculpture, and literature ${ }^{4}$ which helped shaped the cultural landscape of Western Europe, defining on its path, its social and cultural identity.

This paper seeks to discuss the dynamics of identity and dissentas symptomatic of existential angst,reflective of the corrosive moral and social consciousness of the time and the inevitability of the collapse of traditional morality and the birth of alternative truths. The paper equally locates the difficulty of closure with regards to Stephen and Ursula to their avid quest for personal truths that should define their identity.

Among some of the major concerns in Western thought and especially in European world view have been Man's relationship to their creator, his sexuality, the meaning of truth and how it defines our existence, the essence of beauty and overall, the meaning of 'self'. Joyce and Lawrence championed these issues inbothdistinct and convergent ways.They wrote at the time when the quest for new knowledge and the desire to break away from the past was at its apex. It was a period of desire and urgency, new inventions in nearly all fields of life. Political convulsions in Europe $^{5}$ created anguish and fear and caused the gradual

\footnotetext{
${ }^{3}$ She is the most representative of the Lawrence's characters in terms of social dissent

${ }^{4}$ Innovations or dissent against existing norms were brought to bear on; painting, sculpture and literature through amongst others the works of: PabloPicasso,Henri Matisse,George Grosz,Aime-Jules Dalou, Charles-Henri Joseph Cordier, Elie Wiesel,Rainer Maria Rilke,Franz Kafka etc.

${ }^{5}$ These convulsions included among others the development of political liberalism; the struggle by Great Powers to assert global influence; the agitation of new nations that finally led to the first and second world wars. For more of this see J.A.S Grenville's $A$
}

disintegration of Europe's social structure. There was a renewed sense of cultural identity by a new generation of young people who sought to define themselves against the backdrop of their parent's generation. Put differently, there was an inevitable generational conflict that would eventually find its way into music, painting, and literature mimicking the realities of life at that time.

In the political sphere, the surge of national pride and the desire for religious and racial supremacy and the battle for sexual equality all occasioned a new sense of self and imposed a new grammar of understanding of human thought and desire. It exacerbated the immanent political, social, and cultural tensions which were at the crossroads of a new global configuration. Joyce and Lawrence were (even though at some convenient difference) at the forefront of this far leftistmovement of self-propulsion, of a complete annihilation of culturally obfuscating values that were both retrogressive and obnoxious.

It is worthy therefore to understand the relevance of $A$ Portrait and The Rainbow in the present discussion because they reflect the reality of their time, but perhaps more because they introduced into the cultural history of the United Kingdom the contested fabric of identity and dissent in the English society. If the question of identity and cultural self-praise was the new paradigm of twentieth century Europe, it hascontinued to animate western thinking and pride today. Postwar Europewoke up to the realization of the cruelty of human actions, but perhaps also to the shocking awareness of the apparent inaptitude of the Godhead to respond to immediate human suffering. This was not simply the result of a sudden realization. It was the product of a culmination of accumulated frustration resulting from the weariness with Edwardian and Georgianvalues. Joyce's and Lawrence's works epitomize this apprehension and put them on the pedestal of twentieth and twenty first century cultural pyramid. Albeit sometimes in different ways, Joyce and Lawrence contested some centuries old social and cultural values. For Joyce, it was Roman Catholicism and for Lawrence it was the immateriality of Christianity and its inability to resolve Man's inevitable inner conflicts.

The underlying moral fabric of Western existence is anomnipotent, Omni present and benevolent God. Prewar and postwar circumstances ${ }^{6}$ created the conditions for

History of the World:From the $20^{\text {th }}$ to the $21^{\text {st }}$ century (London: Routledge,2005)

${ }^{6}$ Assaults on religion created doubts about and killed enthusiasm towards the divine presence. The works of researchers such as Charles Darwin'sOnthe Origins of Species (Signet Classics,2003) 
Europe to contest this vision and to call into question the ability of a saving God. It created the condition of doubt and exacerbated Western anguish. This theme has been the subject of a great literary tradition beginning with George Eliot and intensifying with Joyce and Lawrence and continuing with Graham Greene, T.S. Eliot, and Samuel Beckett.

Stephen Daedalus and Ursula Brangwen represent each in their own way, a disavowal of the traditions and mores of the social systems of thought that have held sway for centuries. The fundamental rhetoric of Stephen Dedalus in A Portrait rests on his view that belief is fundamental to faith and happiness; with belief gone, the very essence of hope evaporates. This is sacrosanct to and characteristic of western Christian thought and survival. The most difficult thing for Stephen is his inability to believe without questioning and to have faith in a religion that has betrayed Ireland's greatest symbol of freedom. His childhood is jostled by intense political and religious conflict, acute poverty and the psychological trauma caused by Parnell's death, and perhaps most especially, the Church's inability to save him. That sense of betrayal will not only haunt Stephen for an exceedingly long time but will define and shape his quest for self and the necessity to find a different path from the traditional route.The ingredients for dissent are available in Stephen's childhood. They will be the very reason why he loses faith and in losing faith Stephen not only loses the most important element of Christian belief but puts a dent on any possibilities of reconciliation with his family, country, and religion.He wages a war against his own very survival and by extension against the values he stands for and is defined by.

Dedalus' greatest Christian sin is that of defining himself and standing against the very God that has been at the center of the meaning of life in western belief.

I will not serve that in which I no longer believe whether it call itself my home, my fatherland or my church: and I will try to express myself in some mode of life or art as freely as I can using for my defence the only arms I allow myself to use-silence, exile, and cunning. (247)

The above statement is his mea culpa which reflects the extent of his inner struggle and the conclusion of that internal strife.It is a statement that also reflects the anguish of his generation and projects in some sort of ways the moral

and Sir James George Frazer's The Golden Bough (Oxford: Oxford University Press,1994).

ISSN: 2456-7620

https://dx.doi.org/10.22161/ijels.61.19 cataclysm of that generation. Dedalus' disavowal of centuries of values reflect the pathological fin de siècle malaise that was eating deep into and will eventually engulf western value systems. Disbelief has become the defining value to measure the moral health of a generation ridden with skepticism. And Dedalus carries that voice of dissent with an intellectual commitment commensurate to the disparate voices of the time.Stephen's cry of dissent represented above reflect the tipping point of a generation of people disillusioned by the cultural and social standards set for them and determined to create alternative paths of reality. He engages in this discussion in his essay "Home Rule Comes of Age" when he accuses the Irish Catholics of selling Parnell "to the pharisaical conscience of the English non-conformists, without exacting the thirty pieces of silver" (144), a reference to the insanity and silliness of their actions. The Vatican, according to Joyce becomes the greatest enemy of Irish Home rule by both its implicit and tacit complicity.In yet another essay "Ireland at the Bar", Joyce compares Ireland to the innocent Irish farmer in a long forgotten sensational case, condemned and executed because he could not be understood; in the same way Joyce contends that, "Ireland cannot appeal to the modern conscience of England or abroad"(146), because England can never understand her plight.

In the same vein, Lawrence pushes the limits of that cry to breaking points through Ursula who clearly at a certain point represents Lawrence's own voice. Ursula is the culmination of the voice of dissent of her time, but especially of the issues she, like Lawrence, stands for. Set within a world that seems heavily attached to chivalrous values, but which values are threatened by industrialization and the menace of war, Ursula must assert her freedom by expressing with her body the deep recesses of her mind. For Ursula it is the fight of her life; to break the barriers that emotionally and physically suppress her.

Lawrence has a tendency of casting her female characters in some sort of punitive solitude. They end up in some pathetic emotional dependency, but this accusation, (and it is intense among Lawrence's female critics) helps to undervalue the psychic strength of his female characters, and at the same time and paradoxically so, foreshadows hope of a new society. He paints a complex mesh of the intricacies of society and its struggle to pull itself out of the bubble of tradition and continuity. Unlike Stephen, Ursula is shelved into a morbid solitude, which paradoxically is lessa sanction of her moral travesty and more a triumph of change. 
Joyce and Lawrence sought in their various ways therefore to defy the dominant discourses of their time, but more especially the dominant religious and moral thinking of the system of life to which they were born. Their fiction upholds a new standard of reality, as it creates its own system of ideas built on the realization that time and change will ascertain an objective truth. A Portrait and The Rainbow refuse to align with the Bethlehem legend that considers history and time as finite ending in some morose self-pity where happiness is dished out to meritorious souls and endless fire and pain to the sinful. Joyce and Lawrence still tower today like they did yesterday in this world of posttruth, where populist neoliberal thought is opposed to a conservative far rightist affirmation of individualism, where rigid radicalism has become in some quarters the hallmark of a ferocious and blind religious individualism. Stephen and Ursula stand out even today as postmodern individuals fatigued by these various assertions of self, and determined to createa new culture of theirs, one that will define and determine the meaning of their world. Put differently, and read from whatever lens, these two novels continue to fascinate our imagination as they capture an infinite reality and make closure difficult within the context of present day western philosophical, social, and cultural value systems.

Nineteenth century Europe already set the stage for the inevitable tremendous changes in the human society. There were changes in technology that augured a new way of life for man and created a radical shift in Man's perspective towards fellow man.The development of new philosophical, psychological, and sociological currents ${ }^{7}$ in many ways radicalized humanity's conception of itself and his response to the world. There was a greater tendency to rebel against existing standards because these formed the standards of the time.

The Rainbow and A Portrait represented and still do represent different facets of that early twentieth century movement towards extreme liberalism. A better understanding of this will require an understanding of Lawrence's and Joyce's contemporary and their thoughts. Dedalus and Ursula, representatives of this period in terms of gender and ideology,reflect the major currents. The point of convergence between Dedalus and Ursula are their views on

\footnotetext{
${ }^{7}$ The groundbreaking theories of Sigmund Freud in Psychology; those of Emile Durkheimand Max Weberin sociology and Karl Marx. For detail discussions see George Ritzer and Jeffrey Stepnisky's Contemporary Sociological Theory and its Classical Roots (Sage,2018.5 ${ }^{\text {th }}$ ed.) and Bertrand Russel's The History of Western Philosophy(Routledge;2015, ${ }^{\text {st }}$ reprinted ed.)
}

religion, art and love (sex), but perhaps most especially their longing for extreme freedom.

Nineteenth century religious dissension had its origin as far back as the sixteenth century during the reformation but exacerbated during the early and later part of the nineteenth century. This will impact such writers as George Elliot who sounded the note of anxiety inher works. The sense of newness, the desire for change, the feeling of a new beginning was heralded by questions of the presence of God in human affairs and the importance of human endeavour. As far as Charles Dickens, religion was considered not as a symbol of relief but as a tool of oppression. In Silas Marner, it is the very nerve of Christianity which is attacked. God can no longer be trusted to deliver justice; justice must be found elsewhere-perhaps in philosophy, or maybe simply throughself-introspection.

Published within a year of each other, A Portrait and The Rainbow portray characters in search of identity, purpose, and fulfilment, and a society in search of itself. Lawrence and Joyce made bold statements about the inevitability of change and the need to boldly come to terms with it. In both novels however, the authors rallied forces against ultraconservatism. They built the content of their novels on the heels of the modernist movement which main characteristic is innovation as expressed by one of twentieth century's firebrand modernist, Ezra Pound, who said "make it new" no matter the subject (qtd. in Stephen Kern 5). They were interpreting the cultural and political tensions that have always rocked the world in new ways. They set the pace for new narrative methodologies that will eventually inform our perception and understanding of the subject matter and the circumstances surrounding its construction.

Lawrence and Joyce's characters' struggle to find their own religious voices, affirm their sexuality, cope with the pressures of their families, and break free from the constraints imposed on them by their various national values. The key issues of dissent therefore are family, country, and religion. In varying ways therefore, Lawrence and Joyce construct a narrative in which the main protagonists wrestle to free themselves from the demands of their societies. Joyce builds A Portraiton the historical premise of century old Irish religious anxiety and the resultant cultural tensions. Stephen is symbolic of the warring strain characteristic not only of the troubled Irish history but of the cultural malaise that rocked early twentieth century Europe and that persists today in multifarious forms. His development and growth signal the very fundamental crisis of the turn-of-the-century malaise that gripped most European countries and created 
some of its virulentliberal thoughts. At the center of all of this is the new characterization of morality and the imminent disappearance of traditional values that have defined most of Europe's philosophical and cultural thought, actions, and space.

Stephen Dedalus' identity is defined by his resistance against oppressive value systems that make self-realization impossible or exceedingly difficult. His home is one of the places that will set the tone for his self-consciousness and eventually the desire to rebel against the oddities of his society. Stephen's home is a microcosm of the tempestuous Irish environment that gave birth to the irk and anger that saw death and destruction over the years. It served as a platform to gauge his own views, to give him an understanding of the religious dynamics of his society so that he can appropriately navigate them. Dedalus graduates from childlike piety to rebelling against blind Roman Catholic dogmatism. The child-like language of piety in the first part of the book is reminiscent of his innocence and his desire to go closer to things religious and to embrace Christian values. Joyce's use of language correlatesto Dedalus' innocent simplicity and the drive to come closer to his Maker.

The book develops on a significant structural and thematic contrast between its beginning and its end. At the beginning of the book, prayers mean a lot to him, in fact they define his happiness and justify his being. They echo in his mind the spiritual essence of his existence while he is in school. His belief in a divine essence is untainted and is the organising principle of his and his family life. The detail of Stephen's pre-prayer moment where he repeats his prayers "quickly, quickly" (16) and the innocence of the prayer "God bless my father and my mother and spare them to me! God Bless my little brothers and sisters and spare them to me! God bless Dante and Uncle Charles and spare them to me!" (160) are charged with urgency and belief and are symptomatic of unbridled faith. This is what defines the personality of the young Stephen and the society in which he lives.

There are key incidents that define Stephen's later spiritual determination. The Christmas dinner and Stephen's wrongful punishment by the Prefect of Studies' are great moments that shape his thoughts and his eventual rebellion against Roman Catholic religious orthodoxy and Irish political asphyxiation. The dialogue at the dinner table is loaded with symbols and images referencing the political and spiritual deadlock reminiscent of Irish life, but also of Stephen's personality. Dante's dismissive attitude of Parnel on grounds of his violating Christian morality and Stephen's father's violent rejection of God are opposing tendencies in his struggle for survival. They represent the attempt to give meaning to his identity. This Christmas debate reflects the fin-de-siècle ideological malaise on the nature of the turn of the century's new identity. Dedalus' father and his governess represent the traditional and modern dispensations of the time the novel was written. Both currents were struggling to wade the tide of change.For Dante the old order must persist while for Dedalus, change is both inevitable and necessary in the development of a new Irish identity.

The source of conflict between Ireland and Britain is religion, which is equally the main source of conflict in the Dedalus' home. This will be the undoing of their family and by extension himself. Dedalus forges a new identity from the warring values of his home. His growth process is tainted with bitterness and regret ina conflict in which no one is ready to capitulate. The caution from Dante that "he'll remember all this when he grows up," and the bitter retort from Mr Casey that "Let him remember too...the language with which the priests and the priests' pawns broke Parnell's heart and hounded him into his grave" (33) will help to inadvertently define Dedalus' self-identification. At an early age, Dedalus is tormented by contradictory opinions emanating from his father and governess, both of whom have been influential in his childhood and in his present development.

The assault on Irish freedom, Irish identity and Christianity are so intense that Dedalus leaves the dinner table completely and mentally distraught. His father's supposed anti-Christian and outrageous comments "No God for Ireland! ...We have had too much God in Ireland.Away with God",are symptomatic of the sickness of the age. Stephen is mesmerized by this uncontrollable and bitter expression of outrage and is "terrorstricken" (39) seeing his father leave the dinner table in tears. This is the most powerful image that leaves its imprint on the young Dedalus as he leaves his parents' home forthe new reality in college. This image will define him forever and shape his outlook of Ireland and awaken the necessity for personal freedom from the bondage of religion and family. James Fairhall has argued in his discussion of the relationship of Joyce and his works to history, that the Christmas scene emphasizes the church's "intervention in the Nationalists' internecine struggle over Parnell" (126) and the pain of betrayal which has been a recurring feature in the reading of "A Portrait," and in Dedalus' mind. But it is also an issue that calls to question as James Fairhall indicates the dire issue of nationalism and morality. 
European life has always been characterised by the conflation of politics and religion and at each epoch European culture has been determined by these factors. Dedalus represents a new culture, a new Europe struggling to cope with the new dispensation, a more modern attitude towards life and nation.Of all the discussions around Stephen, the one remembered most is the one in his own house. His thoughts and actions are determined by the sociological component of his house. His very survival depends on how much he mitigates the violently opposed views of his father and governess. Joyce builds in the Christmas dialogue irreconcilable facets of Irish national identity, which are the spiritual and the mundane.

Dedalus leaves his house to college determined, albeit unconsciously, to forge his own identity and to chart a respectable course for his life. The college environment will offer him new vents of opportunity where he will try to shape his narrative of self-assertion and impose a cultural ideology of his own. He has the refinedness and insight of an artist and is determined to orientate his spirit towards a more assertive personality. Joyce's difficulty like Dedalus' is how to do this without contravening the Irish laws and rules that according to both character and author asphyxiate the deployment of a meaningful self-portrait. He is caught by domestic inhibition, an educational autocracy, religious dogma and political myopism.

From the onset Dedalus seems to be a product of extreme liberalism, not consonant with British grip on Irish politics. He is like Ursula, an avantgarde character, free spirited soul and ahead of his time. Joyce's eloquent testimony comes earlier in the novel when he characterises Dedalus as "His soul was still disquieted and cast down by the dull phenomenon of Dublin". Joyce pushes this symbolism further when he insists that Stephen finds himself in school in a "new scene, every event and figure of which affected himintimately, disheartened himor allured and, whether alluring or disheartening, filled him always with unrest and bitter thoughts" (82). He naturally aligns himself with subversive writers because in them he finds and can give meaning to his life.The opposition to his views on century held opinions by great Greek philosophers tantamount to a rejection of his self-esteem and thereby produce the impetus to rebellion. Dedalus is suspected by both his teachers and friends and seen as a traitor to both country and church. This seemingly mistaken view of the young man in search of a soul reflects Irish society's search for its own true soul-the search for freedom begun centuries ago and continuing today.
The young Dedalus who takes sides with subversive writers like Byron and Cardinal Newman is equally torn by internal voices that pull him between the fight to rescue his language and tradition and the voice that asks him to move forward and determine a very personal view of life. There is a "worldly voice" that would urge him to raise up his "father's fallen state" and another voice that would ask him to be a "decent fellow, to shield others from blame or to beg them off and to do his best to get free days from school" (88).Dedalus' innate sense of freedom is a driving force for his seclusion because he gave his friends only his "ear" and found happiness when he was "alone" or "in the company of phantasmal comrades" (89).His solitary disposition led him to recoil to himself and only took decisions that had an echo of the "infuriated cries within him" (98).Dedalus seems to have been hibernating in the first and second chapters of the book. He wakes up from the "slumber" whose real benefits have been the realization of his inert abilities and the push to move forward hinged on the realization that, real freedom can only be the result of self-abnegation from national and family ties.

Stephen's character is eventually shaped by family, nation, and religion. In the first two chapters of the novel,he wrestles with these issues and begins to understand that his personal freedom will be the direct result of his ability to navigate the nexus of family, nation, and religion. He sees these as the steppingstone to his philosophy of self-expression built on personal rather than communal beliefs.

In Dedalus' early-stage home and school free him from the throes of political ignorance. His parents and relatives act as eye openers to the biggest question of their time- Irish freedom, but also to the bigger questions of individual destiny. Dedalus, naturally caught between these two extremes represents the subtle intermixing of the passing and the incoming generation. The frank discussions at home and the subversive writers he reads in school all help to develop in him a sense of personal awareness. In his own philosophical thought and perhaps even unconsciously, it is in charting his personal moral and aesthetic trajectory that he can successfully develop his own theory of self.

Dedalus dangerously navigates the nexus of religion and politics, and philosophy and art. These are concepts that define his identity, portraying his 'modern' nature and foreshadowing the intellectual malaise of the century. The political schisms in Europe at the turn of the twentieth century shaped the social consciousness of the time.Joyce and Lawrence translated this into fictionalised accounts of Europe's war with itself. The religious awareness brought 
about by political turmoil put into perspective the inevitable cultural changes that would shape the thoughts and actions of Joyce's world.

Dedalus is in many respects the real image of the political and religious anguish of his time. With his family being the centrepiece of that crisis, a crisis that occasions the desire to have the long cherished Irish identity. The Christmas diner quarrel sets the stage for fundamental issues that define both the character of Dedalus and his desire for the new Irish identity. In pitting Simon Dedalus and Riordan Dante against each other, Joyce creates a verbal battlefield that will lay the foundation for both Stephen's rebellion and his political assertion. Between his father and his governess, Dedalus will find a path akin to his philosophy of Irish identity and how that identity should subsume into the new cultural landscape. Dedalus is disgusted by the treacherous attitude of the Catholic church in its treatment of Parnell and is the more appalled by his father's description of Irelandas "an unfortunate priestridden race" and at the same time fascinated by his governess' believe that the priests are "the apple of God's eye" (37). For both parties, the battle lines are drawn and the young Dedalus has to figure out the middle way out of this.The impact of this on theyoung Stephen will be very profound in his subsequent interaction and development as was the case with his creator, Joyce, who was caught in the ethos of what Joseph Valente views as the repressive nature of "Irish Catholic nationalism" (43) and at the same time caressed what Valente will call the "masculinized and English identified pursuit of individual self-interest," (43).

Brought up in conservative Roman Catholic tradition, Dedalus's faith is put to test by this overwhelming difference of opinion. The family becomes both the source of tension and the epicentreof Stephen's identity and eventual dissent. Joyce uses this medium to portray the antithetical relationship between them and how suffocating they are.He was aware that he was creating the conscience of the Irishrace as he wrote to Nora "I am one of the writers who are perhaps creating at last a conscience in the soul of this wretched race." (SL 204 in Valente 42).

Simon Dedalus's fury is equal to Dante's disregard of the corrupt political establishment. The church's relation to the political establishment is the source of the conflict within the text. In re-echoing it here, Joyce foreshadows its inevitability and the dangers it presents in modern politics. The ultimate point of this argument is Simon's uncontrollable tirade “... if it comes to that, no God for Ireland!" (38).That he re-echoes this over and over shouting desperately that "We have had too much God in Ireland.Away with God" (39), should be the greatest scandal in modern English novel.This is the culminating point of his anger and desperation, which are only accentuated by Dante's violent "Devil out of hell! Wewon! We crushed him to death! Fiend!” (39).

Dedalus' is "terrorstricken" seeing his father cry during the ensuing Christmas diner quarrel. Perhaps the most affective thing he will see are the tears running down his father's face. The gestation process for him will be a hallowing period with memories of bitterness. The family, aplace of comfort has become the hallway of violent disagreement. Dedalus' household is a microcosm of Europe and its turmoil at the turn of the century.In his childlike quiet and innocence, the young Dedalus is crushed by the weight of the difference which will eventually lead him to make a prominent statement on Irish identity and life. His identity will be formed by disparate opinions and by reclusion.His father represents the future of his thoughts and by extension Irish thought and identity.

Simon Dedalus represents new political openings, a bold statement on the way we view religion in relation to ordinary life. The foundations for dissent are built from the inability of the adults in the house to reconcile their egos and to accept change as an inevitability. Dedalus will move onto life with the belief that he has to fight for a new way of lifefor self rather than for country, because as he will say later, "Ireland is the old so that eats its farrow..." (39). Joyce understood the dangers of hanging on to the whole idea of nationality and this determined both his conception of Stephen's reaction to it and his own decision to go on selfexile. His understanding that nationality "must find its reason for being rooted in something that surpasses, transcends and informs changing things like blood and the human word" (CW 166.qtd. in Theresa O'Connor 100).Stephen understands that the purification of nationality must be done against the backdrop of cleansing which includes blood ceremony. A big question in Joyce's recollection of the Irish nationalist myth is whether Stephen succeeds in this or he undermines it. His self-exile represents in some respectsa sacrifice, for the rejuvenation of the nation. Joyce was conscious of this burden, as early as 1912 as indicated by Ian Crump, when he wrote to Nora "I am one of the writers of this generation who are perhaps creating at last a conscience in the soul of this wretched race" (SL204, qtd in Ian Crump 231). This became the overwhelming concern of his life as an artist, to wit, both demythologizing and emphasizing the myth of nationality. In concluding the novel with Stephen's diary, Ian Crump argues that it is an 
indication that as an artist Stephen "remains doubly ensnared by his desire to be a discursive authority and his inability to communicate with anyone other than himself" (235).Perhaps this is an expression of his fears of being misunderstood on the subject so dear to him and all his countrymen.

In both The Rainbow and A Portrait, the family is the foundation of growth and the source of vitality for the young characters. Dedalus and Ursula are forged by the dynamics of their various families. Ursula is the product of a third generation Brangwen, which notwithstanding has been imbued with certain cultural and social values. However, like Dedalus, Ursula has seen enough of her family either clinging to those traditional values or refusing to ascertain the truth of the new values brought about by time. Unlike Dedalus who is influenced by his family circumstances which leave him conscious of the disparity that exists between his parents and the governess, Ursula is much more self-conscious at a youngage. She has determined that her mother, Anna, is servile and too feminine, that she would rather look up to her father to create and form her own identity.

Ursula's mother, Anna is more resilient than her own grandmother, Lydia, who despite her internal energy could not rise to the overwhelming presence of her husband's imposing self. She is in the line of resistance bent on making her own way out of life and imposing her own reality. Her mother had set the pace for this by attempting to break loose from the claws of her husband's drudgery. She hates his blind devotion to church and the church symbols and questioned male virility and female lack of assertiveness represented in the paintings in the church.

Lawrence pulls down the curtain on Anna's psychic strength by associating her only with the happiness of childbirth. Feminist critics of Lawrence have often used this backdrop as an example to ascertain femaleness only in terms of childbirth and maternity. Her cry of "Anna Victrix" (178) is associated only with maternity and not with bold representation of some form of ideology. She considers William as a reality only in conjunction to his being a father. In their new-born baby, Anna recognizes William as agency. Her "Pisgah Mountain" (180) is her feeling of woman. It is her own rainbow, the multiple filaments of success. She is a source of life to a new generation and her rainbow may not be contentment with maternity, but rather the birth of anew generation of the Brangwens who are ready to scale the walls of the world in search of new forms of reality and truth. Ursula Brangwen will come to represent a robust and new cultural identity.
Ursula is the product of an inevitable and progressive cultural development determined to assert itself. If Anna found closure in childbirth, Ursula's single battle is to free herself from the grip of "ultimate confine" (187) about which her mother has started wrestling with.Ursula's resentment of her mother is rooted in her believe that her mother has only "superficial authority" (201) while "she was wakened too soon" (204). UnlikeDedalus, Ursula is assertive, intuitive and asks the right questions. The answer her grandmother gives her to the question as to whether someone will love her is very telling of the rather unfamiliar environment.The core of that answer is Lydia Lensky's belief that someone will love Ursula "for what you are,and not for what he wants of you.But we have a right to what we want" (241). This justifies her quest for self-identity. More than perhaps anyone else in her family, Ursula's grandma has spoken what will seem to her as the ultimate truth. This is the gospel by which Ursula will live and determine her life changing decisions. She is defined by this belief and her actions are determined by the desire to extricate herself from the traditional values of the Brangwen that are determined to limit her possibilities of expression.

The Rainbow as Alastair Niven has indicated chronicles the life changes of many ages and generations, with the Brangwens being representative of this historical change. According to Niven, Lawrence's intention was to show the Brangwens as representing their types and circumstances. Niven contends that Lawrence hoped to show the Brangwens "as part of the evolutionary process by which man in England had arrived at his contemporary condition" (64).Ursula Brangwen is at the tip of this evolutionary movement towards a new individuation, reason why Ursula Brangwen could be "the most life-changing character D.H.Lawrence ever created" (Niven 86).Niven will go further to argue and correctly that "Ursula's great task in life is nothing less than to make sense of the evolutionary process and her place within it. 'Out of nothingness and the undifferentiated mass, to make something of herself!"” (Niven 283)

In Joyce's and Lawrence's worlds, the family played varying roles in foreshadowing the cultural identity reminiscent of the generation portrayed by both authors. Stephen and Ursula grow from different family backgroundsbut their determination to create a new identity for themselves reflect the courage of their time and the desire to break free from the moribund values that hold sway in their environment. While the scientific and political theories of the turn of the century and murderous conflicts helped to shape 
the consciousness of the people at the time, one cannot underestimate the very fundamental fact of the importance of the family in building a new cultural identity for the modern individual. The Brangwens and the Dedalus are the microcosm of a society symptomatic of the necessity for change. Lawrence and Joyce put the family at the center of change as it represents the very nature of society.

Joyce and Lawrence were conscious of the value of education in shaping the minds of the modern character. Dedalus is forged by the rebellious truism of writers such as Lord Gordon Byron and Percy Bysshe Shelley. His heretic essay is a confirmation of his own sense of freedom, the inert desire to explore his own inner world. Reeling from the humiliation he suffers in class, Dedalus soon learns thathe must chart his own way out of the traditional concept of sin and punishment taught in Roman Catholic doctrine and promoted in the Jesuit schools he has attended. The psychological torment Stephen undergoes in school, born from the hatred by his mates of his choice of authors in school bolsters his rage against their shared values and creates his determination to enunciate his own truth. Dedalus grows from the crawling little boy shaped by incontinent arguments at home to the motivated young student ready to stand up to the Prefect of Study and his classmates to an intellectually equipped adult building on the theories of the great philosophers to construct his own identity.

The moral and psychological development of Dedalus is equally forged by his school environment in Belvedere. The refusal of his classmates to acknowledge his intellectual orientation creates a definitive resistance against the suppression of his identity.He takes sides with protest writers who have created a scheme that identifies them from the ordinary sing song writers who do not or refuse to have the courage to make bold statements about life. Dedalus' education help develop many silhouettes of identity from which he will create his own.In pitting Dedalus against his classmates at school, Joyce subtly brings to light the intellectual arguments of the time. Dedalus is simply at the end of the novel, a product of those arguments.

It is through the "eyes of his mind" (91) that he will awaken from "a slumber of centuries" (107). The rollover from the past into the present and into the future is a simple matter of developing a different kind of consciousness.Joyce's $A$ Portrait runs through five chapters developed from childlike sensations through teenage consciousness to the vagaries of adulthood with its attendant innuendos. The formative years of Dedalus at school are the cornerstone of his identity as they justify the quarrels at home which are representational of the larger Irish quarrels. Lawrence draws the same inspiration when he aligns Ursula with her class mistress Miss Inger. She is awakened to another form of consciousness not by the teachings of Miss Inger, but by the latter's personal demeanour and life. Her solitariness and her independence of mind are a galvanising factor for the young Ursula in search of her own identity.

Ursula sees in Winifred Inger a representation of the cultural shift that the century was witnessing. Lawrence does notdevelop Ms. Inger's character probably because of his distaste for her style of life.This however does notmitigate the effect her short relationship with Ursulahas on the young woman.She has an "indomitably proud nature"and she is"as free as a man" (312). This is the new identity that Ursula is craving for;even though Lawrence always succeeds to undermine women's attempts to be themselves by indexing their freedom to men's. The ultimate quest of Ursula is to be her own person.Her rejection of Winifred Inger's invitation to follow her to London is the ultimate assertion of self. Inger is an idol figure representing the female essence of self at the time.By rejecting any further associations with Winifred, Ursula pushes the frontier of "self" to thin levels with the ultimate desire of being "myself” (319).

In The Rainbow, Lawrence has the attitude of undermining women's attempts to self-identification. Winifred Inger's marriage to Tom Brangwen is one such moment where the author undercuts Ursula's reverence for a supposedly enlightened woman by making her end up only in the arms of a man.In so doing he ridicules Ursula's feminist fervour and undermines her attempts to rise above her society or its traditions.

The religious question is a more defining issue in the transformation of character at both novels.Charles $\mathrm{M}$. Burack, discussing Lawrence's the reader's immersion in The Rainbow contends that Lawrence plays with both the structure and character of the text making it appear as if he is "the conductor of a religious initiation rite who leads novitiates through a series of transformative experiences designed to culminate in the awareness of or union with the divine." (166). The ultimate aim of Lawrence,Burack argues is that he eventually leads his characters to a contact with an "immanent divinity" (167). Stephen and Ursula both fit this characterisation as they meet obstacles and work hard to purge those psychological obstacles that hold sway in their societies and eventually stimulate their own spiritual awareness and define their conscious identities. Even though characterised from different perspectives, the grand objective among these early writers was to point to the transformative 
powers of religious dissent. Dedalus leaves his house pregnant with dissenting religious ideas born out of the disagreement between his father and governess. The school environment does not make it easier for him to ease these tensions as they rather amplify them and create a greater chasm between him and his original piousness. It is in school that the young Stephen hasgreater understanding of the inextricable relationship between religion and politics and how both help to stifle Irish freedom.

In associating Christianity with politics,Joycebrings to the forefront the tragic imbroglio of the Irish who are thrust between Roman Catholicism and political realism. Dedalus carries this consciousness to his educational environment at Clongowes and Belvedere.His rebellion against Roman Catholicism is animated by the belief that the incestuous relationship between the church and political institutions is at the origins of the sufferings of the Irish and their inability to establish their own political institutions. His choice of authors and his refusal to accord any importance to Cardinal Newman's treatise on the nature of universities, are the direct result of his anger. Stephen's disregard for Captain Marryat and Alfred Lord Tennyson, and his love for Lord Gordon Byron reflect his mindset. This attitude and is a direct statement on his growth as an individual free from the vicissitudes of family and nation.

The sins of Ireland are those of the Catholic church since one cannot dissociate each from the other. Joyce paints a character who struggles to free himself from sin not because he is very remorseful and intends to follow a pious path but simply as an attempt to wrestle himself from the religious sloppiness that his family and nation have put him in.Joyce describes Dedalus as having a "loveless awe of God" and his allegiance to Him is simply a "false homage to the Allseeing and Allknowing" (111).

Stephen is overwhelmed by his moral squabbles and in an epic rendition of his struggle to overcome sin, Joyce portrays himas being mortified by his sexual gratification and overwhelmed by the desire for repentance. He is awakened to the immorality of his sexual sins by the preacher's incisive teachings "The preacher's knife had probed deeply into his diseased conscience and he felt now that his soul was festering in sin" (123).

Chapter three of APortraitis the exorcist section of the book where Dedalus is exorcised of his sins and apparently forgiven. It is also in this chapter that he will understand his own mission as an artist. He will not serve that for which he does not believe in.The confessions and the preaching all prepare him to his ultimate denial of Christian truth and the assertion of his own inner belief.He forsakes the truth of God, in favour of his personal beliefs. The following lines reveal his goal which are "Another life! Alife of grace and virtue and happiness! It was true. It was not a dream from which he would awake. The past was past" (158).

Joyce's irony is apocalyptic as it situates the reader and Stephen in a perspective of moral disaster, but which eventually leads to personal freedom. The preaching does not bring him closer to God, they rather alienate him from the "Allknowing" and create a big chasm between him and the society. But they help him to understand his life's mission and the determination to move on. It is a watershed moment that will define his stance vis-à-vis the society of faith and erect him to the towering personality that he aspires to be. His confessions are simply "a channel for the escape of scrupulous and unrepented imperfections" (164) and not a true assertion of faith in a blind religiosity.It is a catalyst to an imperturbable reality because "His destiny was to be elusive of social or religious orders. The wisdom of the priest's appeal did not touch him to the quick. He was destined to learn the wisdom of others himself wandering among the snares of the world" (175). This is a more fundamental thing to do in the elevation of his soul. The bread of life is the spiritual entity of the artist. It is the absolute freedom to dwell in unimaginable places. His name which is "a symbol of the artist forging anew in his workshop out of the sluggish matter of the earth a new soaring impalpable imperishable being", compounds with his artist soul which is "soaring in an air beyond the world and the body he knew was purified in a breadth and delivered of incertitude and made radiant and comingled with the element of the spirit"(183).Dedalus is in a state of ecstasy because of the "call of life to his soul not the dull gross voice of the world of duties and despair,not the inhuman voice that had called him to the pale service of the altar." (184)

The romance between religion and politics in Dedalus' house gives way to a new and more meaningful relationship, that between art and truth which is a more appealing reality to him. Truth to Dedalus is the inner spirit of art and it is it that which defines the very identity he aspires to. Christian preaching has elevated him to the point of understanding the essence of his life and the mission of his being. The picturesque portrait of the girl his soul encounters is the culminating point of that aspiration and the revelation of the ultimate understanding of what he must do for himself and for humanity. The deep cry of joyful distress "Heavenly God! cried Stephen's soul, in an outburst of profane joy" 
(186), translates the symbolic revelation of the truth he has been searching for.His moment of epiphany is the ultimate break off with the past and an affirmation of a new identity born out of the desire to create an alternative reality. The girl's figure represents to Dedalus "an envoy from the fair courts of life, to throw open before him in an instant of ecstasy the gates of all the ways of error and glory. On and on and on and on!" (186).Dedalus reveals himself to us as a product of resentment of the culture and politics of the time.He is a symbol of the soaring identity of the generation of young people determined to shape their own future by charting their own paths. He represents a revolution that is bent on defining new strategies of life, new modes of assertion and new paradigms for religious assertiveness. His character is built on an avid desire for change and his identity is defined by dissent.

Joyce builds the tension in A Portrait against the backdrop of a long-standing tradition of criticism against the authoritative Christian demand of the "singularity of purpose", modelled against Jesus' claim that he is "the way" as Stephen Kern puts it. Modernists thinkers and religious reformists assailed this dictum even before the twentieth century, but the assault on Christian authoritarianism exacerbated in the twentieth century and as Kern would argue, these challengers viewed the "organic model as romantic biology and interpreted the idea of an ultimate purpose in life as naïve idealism". These challenges included inter alia the notion of person progress being the result of cumulative assertions and more of "a process of repeated self-criticism and reconstructions" (Kern.40). Self-criticism rather than an essentialist diktat therefore becomes the path forward towards self-regeneration ${ }^{8}$.A portrait inadvertently follows this structural pattern.

The novel itself develops on the premise of innocence, knowledge, and rebellion. Stephen's character is cast against this background. His growth, development and sophistication are inextricably linked to the growth, development, and sophistication of the novel. The little boy who fusses around with the parents at the Christmas dinner and is awestricken by the verbal violence of the elders at table is not the same by the fifth chapter. His growth corresponds to the eventual flight that Dedalus' spirit will take in a bit to accomplish its mission of self-assertion and self-vilification. By the time Joyce takes us to the last chapter of the book, Dedalus is a mature man with set ideas, ready to challenge albeit

\footnotetext{
${ }^{8}$ For more on this view, see Friedrich Nietzsche's Thus Spoke Zarathustra.
}

unsuccessfully agreed upon views on art, truth and beauty which in essence are elusive and undermine the very notions of truth. The psychological and physical growth of Stephen is parallel to the development of language in the text. In detailed explanation of this, Steven Connor argues that in $A$ Portrait of the Artist as a Youngman "growth into one's own distinctive language is in fact a process of adjustment to the language of other, as it is encountered through reading,instruction, and the discourses of social life" (42).This is perhaps the reason why in spite of his protest against the English and his desire for Irish or Gaelic to be at the center stage of Irish life, it never did really happen even in his fiction. As O'Connor would argue, Joyce, like Beckett after him, gradually abandoned the dream of an "authentic language" (43) in favour of a situation in which all language are both " "familiar and foreign" "(44).Stephen's progress is associated as O'Connor states to his "enlarging selfconfidence and critical awareness" (44). There is no doubt that the Irish question was a fundamental one but more importantly the language component. Margot Norris, records that writing to his brother Stanislaus in 1906, Joyce stated that "If the Irish programme did not insist on the Irish language I suppose I could call myself a nationalist. As it is, I am content to recognize myself an exile" "(3). And this will define his character and being and those of his artist creation.

The great consciousness of Joyce is revealed in the last chapter by the portrait of his character Dedalus, who is awakened to the great realization that he can express informed views on the nature of the English Language, Roman Catholicism, and Irish politics.More than anything else,Dedalus is awakened to the realization of the nullity of religious formation, but also to the fact that the Irish mistakenly subsumed their political life into Christian ways of life.

Stephen Dedalus is defined notably by his rebellion against accepted religion, and also by his defiance of imposed cultural values such as language and the way politics is conducted. Perhaps his greatest defining moment is his violent response to Christianity which according to him is the sole reason why Ireland is in the state in which it finds herself. Dedalus' sulphurous and spurious attacks on Irish politics echo strongly when he says to his friend Davin, that "Ireland is the old sow that eats her farrow" (220). He contends that the Irish soul is entrapped in the net of nationality, language, and religion. And this is precisely from where or what he will try to fly. The image of the old sow that eats her farrow can be reverted to the struggle to break away from the past. It reminds him of the necessity of

\section{ISSN: 2456-7620}


flight and concurs with his name and the mythological symbol it represents. Joyce's irony in comparing Ireland to the old sow that destroys its own progeny indicates the power of the nation to self-destroy and by implication therefore the necessity and perhaps the impossibility to escape. In his discussion of the relationship between Freud and Joyce, Brian Shaffer references Jeremy Hawthorn who contends that "few novels show their characters less as free, autonomous beings or more tied to their society and its history" (qtd. in Kern 75). Kern concurs in acknowledging that none of Joyce's characters succeed to accomplish the fit of freedom-of escaping from the unholy trinity of language, nationality and religion. The extent of the truth of this statement lies in the very theme of the book. Stephen is imprisoned in the bubble of self-deprecation, the result of Ireland's inability to free herself from the throes of the cultural wars of her time. However, Stephen like Joyce succeeds at least in putting forth the argument, and in some ways that sounds like freedom of sorts. Drawing from Basil Hallward's discussion on the separation of the soul from the body Garry Leonard argues that if one hopes to create Art then they must preserve the soul even if one loses the church. His contention is that losing faith should not be synonymous to losing the soul because if this does happen, then the artist will only produce what is vulgar and vapid. Stephen, Garry argues will not serve the church so that he can save his soul and thereby save Art. Garry sees Stephen's renunciation of his Catholic faith as "a necessary process on his way to pledging his devotion to Art" (7).

The ultimate rebellion in A Portrait is Dedalus' non-serviam assertion. His greatest statement is to Cranly when he unapologetically puts forth what is in my opinion his lifelong creed "I will not serve that in which I no longer believe whether it call itself my home,my fatherland or my church:and I will try to express myself in some mode of life or art as freely as I can and as wholly as I can, using for my defence the only arms I allow myself to use-silence,exile, and cunning" (268-269).In his refusal to serve that which he does not believe in, Dedalus opens his own path to identifying himself and his kind as alternative truths to the existing circumstance surrounding him. Alan Warren Friedman indicates that Stephen's failure to serve is the result of his understanding that neither his father, church or society can lead him to the realisation of his own potentials, especially as he sees their behaviours as anathema to truth and a barrier to his own essence. His attitude is symptomatic of his society and is reflective of the imminence of change and the construction of a new identity. This Luciferian utterance is the ultimate rebellion and the final revelation of who Stephen is and on what his future is shaped. Stephen like Lucifer does defy the 'unholy trinity' of family, nation and religion, which are in his own opinion the source of his anguish.While the three issues named above are cultural in nature, they constitute in the larger sense of the word a political ideology. Joseph Valente has argued that Stephen's "non serviam" "has political as well as religious meaning, precisely because Irish nationalism has constituted itself as a religion" (37). Irish nationalism is a cult with dogmatic underpinnings and to tear oneself away from it is a sort of heresy. And that is precisely where Valente assertion in my view has a more significant meaning.

Dedalus is aware like Joyce of the difficulty of dissociating himself from the rest of his kind and his beliefs and takes responsibility for his loneliness. In so doing, he underscores his solitariness but also foreshadows the alternative society of his generation.In his struggle to assert this, he affirms that he is not afraid to make a "lifelong mistake" (269) which is precisely the point of his assertion and perhaps his triumph. The new life awaiting Dedalus is the life of solitariness and it is the new beginning for which he is ready to sacrifice.Dedalus has shaped his consciousness from the baseof Irish politics and society and from the unholy trinity of family, religion and country. They serve as springboards for him to define and defend his own consciousness of them. Through him, Joyce passes judgement on the sustainability of traditional consciousness; and the birth of a critical consciousness of self-propulsion which will become the modus operandi of a new culture of life. Stephen embodies the embolden generation determined to subsume themselves in a new wave of action and being.

While Dedalus in A Portrait must fight with the trio of church, family and country, Ursula, representative of the new woman, has to fight with men's hegemony and the strictures of a social system built on hardened patriarchy. $\mathrm{Mr}$ Harby, the school principal and Anton Skrebensky Ursula's lover, both represent extreme facets of the difficulties Ursula must break from if she has at any point to ascertain her own merits and give meaning to her own reality. Lawrence's description of Mr. Harby mirrors the strenuous relationship Ursula has with men but also the kind of society she must navigate through.Harby is "so strong, and so male" with a "heavy jaw,the big, overhanging moustache' with a "certain blind, native power" (360). This is what "She was going to fight and subdue" (368). Lawrence accords Ursula some form of short term victory especially during her relationship

\section{ISSN: 2456-7620}


with Anton Skrebensky. But that is only to undermine her strength and show the limits of her ability and possibilities.

Both Dedalus and Ursula crave for a new reality. They crave for the moon. While Dedalus rebels from beginning to the end, Lawrence undercuts Ursula by making her acknowledge her shortcomings. She talks of feeling "remorse" for her "perverse wicked behaviour" and her inert desire to "have the moon for my own" (450). I had argued in a previous article that in spite accusations of Lawrence being antifeminist, he has shown the extent of women's abilities. His women have enormous psychic strength which they use to dominate their male counterparts. That fact does not in any way undermine the trove of evidence that portrays his inclinations to stick to the traditional relationship of the woman to her society. In a moment of epiphanic stream of consciousness, Ursula questions "why must one climb the hill? Why must one climb? Why not stay below?" (456). Ursula in the mind of the narrator goes on to question her own judgement by asking "Who was she to have a man according to her own desire?"(459). A cursory look at the mindset of the narrator and author, one will find the paradox of change in The Rainbow when there will be "the earth's new architecture" rising from the "old, brittle corruption of houses and factories swept away" (460). Ursula remains according to Fiona Beckett, the only Brangwen who by the end of the novel has "an individuated consciousness" (54). She has broken away from the crowded field of the Brangwens and even though not completely affirmative, she is a new character coming to grips with the realization of self-identification. She is entering into a posthuman "future of hope and human survival that is utterly joyous" (206) as Colbrooke Claire would describe it.Even if some critics do no read Ursula's new engagement with the world in that regard, that is precisely how she envisions her life post Brangwens.

Aclose reading of the two texts and a close look at their various endings show that Lawrence and Joyce had the same pre-occupations about the mutations from a traditional conservative view of their heroes' society into a more urbane and liberal one.In both novels, the heroes however had different conceptions of freedom, change and inevitability. For Dedalus, the shackles of church, family and country must be broken for a new society to emerge. Stephen Kern believes that "Stephen's is the prototypical modernist scenario of the artist in exile from the values that have lost the ability to give life meaning" (213), and for Ursula, one must fight the hard conservatism of the Harby's if one must make meaning out of the complex matrix of a world dominated by unbending patriarchy. Lawrence, however, does not give closure to the attitudes and psychological growth of Ursula, even though he opens a vent in that regard. Niven conceives this open-endedness in a different perspective by arguing that it "illustrates Lawrence's uncertainty of attitude towards the industrial life and the role of authority in society." (93-94). This issue, Niven concludes will be resolved in Women in Love. In both cases, Stephen and Ursula are defined bytheir dissent against moribund cultural values and their identities are shaped by this same rebellion. Consciously or unconsciously, Joyce creates a narrative where the protagonist battles with a suffocating Judeo-Christian morality that denies reality and authenticity in his attempts to create impartial self.

\section{REFERENCES}

[1] Akca, Catherine. "Religion and Identity in James Joyce's $A$ Portrait of the Artist as a Youngman". Epiphany.vol.1, no.1, 2008.

[2] Burack, Charles M. "The Religious Initiation of the Reader in D.H.Lawrence'sThe Rainbow". Mosaic: An interdisciplinary Critical Journal.vol.33, no. 3, (September 2000), pp.165182.www.jstor.org/stable/44029701.Accessed 15 Dec.2020.

[3] Colbrook,Claire. "Futures".The Cambrideg Companion to Literature and the Posthuman. Edited by Bruce Clarke and Manuela Rossini. Cambridge UP,2017.

[4] Connor, Steven. Writers and their Works. $2^{\text {nd }}$ edition. Northcote Press, 2012

[5] Crump, Ian. "Refining himself out of existence: The Evolution of Joyce's Aesthetic Theory and the Drafts of $A$ Portrait. Joyce in Context edited by Vincent J. Cheng and Timothy Martin. Cambridge UP,1992, P.223-240.

[6] D. H. Lawrence. The Rainbow. Everyman's Library, 1993.First published 1915.

[7] Friedman, Alan Warren. Stephen Dedalus's "non serviam." Patriarchal and performative Failure in "A Portrait of the Artist as a Young Man". Joyce Studies Annual.Vol.13 (Summer 202). PP. 6485.JSTOR.www.jstor.org/stable/26285158.Accessed 9 Dec. 2020.

[8] Gardner, Kimball; "James Joyce and His War with the Catholic Church". Scholarsarchive.byu.edu/English symposium/2015/JamesJoyce/1/Ingersoll, Earl. "D. H. Lawrence and James Joyce: The Odd Couple of Literary Modernism." The D.H.Lawrence Review.Vol.38.no.2, (2013), pp.1-20.

[9] Ingersoll, Earl G. D.H.Lawrence:Desire and Narrative. UP of Florida,2001

[10] Joyce, James. Occasional,Critical, and Political Writing. Introduction by Kevin Barry and translated by Conor Deane. Oxford UP,2000. 
[11] Joyce, James. A Portrait of the Artist as a Young Man. Introduction and notes by Seamus Deane. Penguin Press, 1964.

[12] Kern, Stephen. The Modernist Novel. Cambridge UP,2011

[13] Leonard, Gary. "Soul Survivor: Stephen Dedalus as the Priest of the Eternal Imaginat." Joyce Studies,2015, pp.3-27. JSTOR, www.jstor.org/stable/26288823.Accessed 9 Dec. 2020

[14] Levin, Harry. James Joyce:A Critical Introduction. Faber and Faber, 1960

[15] Niven, Alastair. D. H. Lawrence. Cambridge UP,1978. (reprinted 1991)

[16] Norris, Margot.The Value of James Joyce. Cambridge: Cambridge University Press,2016

[17] O'Connor, Theresia. "Demythologizing Nationalism: Joyce's Dialogized Grail Myth" Joyce in Context edited by Vincent J. Cheng and Timothy Martin. Cambridge UP,1992, P.100-121.

[18] Sargent, M.Elizabeth et al., editors. Approaches to Teaching the works of D.H.Lawrence. The Modern Language Association,2001.

[19] Shaffer, Brian W. "Joyce and Freud: Discontent and its Civilization" Joyce in Context edited by Vincent J. Cheng and Timothy Martin. Cambridge UP, 1992, P.73-88.

[20] Valente,Joseph.James Joyce and the Problem of Justice; Negotiating Sexual and Colonial Difference. Cambridge UP,1995. 